\title{
BLINDING IN PEER REVIEW
}

\author{
Christian A. Tomaszewski, MD, FACMT, Editor-in-Chief, Journal of Medical Toxicology
}

On March 14, 2008 a U.S. District Court in Michigan made a decision to protect the confidentiality of the peer review system for medical journals. Pfizer demanded to see all documents dealing with the identities of peer reviewers and all comments regarding the acceptance or rejection of manuscripts on the topic of celecoxib and valdecoxib. This was in response to over 3000 lawsuits Pfizer was defending. The suits alleged that false representation regarding the safety of these cyclooxygenase- 2 inhibitors was made by the drug company. The court refused to allow Pfizer access to those documents [1].

But is the sanctity of confidential peer review all that important? The Journal of Clinical Investigation began using editorial peer review in 1942 when the editor started sending papers to experts outside the editorial board for evaluation [2]. Even today, peer review is alive and well as demonstrated by a recent global survey of the attitudes of 3040 academic researchers [3]. Of those academics, 93\% felt that peer review was necessary, with most authors feeling that the process improved their last published paper. Double-blind peer review (in which the reviewers' and authors' names are not disclosed to one another) was seen as the most effective method, preferable to $56 \%$. Open review (where both authors' and reviewers' names are divulged) was deemed to be superior by only $25 \%$.

Critics of the popular blinded system of review claim that more openness would decrease biases. Reviewers can have multiple conflicts of interest that could easily influence their decision or promptness. If doing research in the same area, which is highly likely, they could vote for rejection to delay publication of the work [4]. Junior researchers may also be reluctant to criticize the work of their senior peers. By hiding behind anonymity, such bias may not be apparent, avoiding the issue of public accountability. By removing anonymity, the reviewer may be pressured to do higher quality work. Unfortunately, multiple studies show little to no improvement in review quality when reviewers' are forced to sign reviews [5-9]. And blinding may be confounded by the fact that in up to $50 \%$ of cases the reviewer infers correctly either the contributing institution or author.

There may also be unintended consequences from nonblinding reviews. Forced signing makes reviewers less likely to recommend rejection [9]. Even worse is the fact that unmasking reviewers also makes them less likely to agree to review a manuscript [5]. In addition, there may be an occult bias toward acceptance with unmasking because reviewers prefer to sign a review recommending publication [6]. The end result is that in a nonblinded journal, reviewers may shy away from papers they feel may end up being rejected.

Finally, there are workflow implications that occur with open review. Unblinded reviews take significantly longer to complete [9]. Anywhere from 23\% [9] to 57\% [5] of reviewers are unwilling to sign their reviews. Therefore, a substantial number of potential reviewers may decline participation in an open-review process. With overwhelming support for the double-blind system, it is not surprising that $47 \%$ of reviewers stated they would be less likely to review if their name was disclosed to the author [3]. With expansion of the scientific literature and the seeming scarcity-especially at The Journal of Medical Toxicologyof potential reviewers, this is a significant barrier to an openreview process.

There is no perfect system for prepublication review of scientific manuscripts. Accountability is the biggest issue for the double-blind method. However, most reviewers still feel that this method works best, ensuring that biases are kept to a minimum. Newer methods, such as voluntary open review, have floundered [10]. Add to this the increasing scarcity of reviewers. The popularity of double-blind peer review is here to stay, including here at JMT. And now, thanks to a challenge from a drug manufacturer, we know that the confidentiality and sanctity of the process is protected by U.S. federal courts.

\section{REFERENCES}

1. Keys A. In Re: Bextra and Celebrex marketing sales practices and product liability litigation. Case No. 08 C 402. US District Court, Northern District of Illinois, Eastern Division (March 14, 2008).

2. Wilson JD. Peer review and publication. The Journal of Clinical Investigation,1974;61(4):1697-1701.n 1974;54(4):vi.

3. Publishing Research Consortium. Peer review in scholarly journals: Perspective of the scholarly community-an 
international study. London: Publishing Research Consortium; 2008,pp. 1-80.; 80.

4. Weller AC: Editorial peer review: Research, current practices, and implications for librarians. Serials Review 1995;21(1):53-65.

5. McNutt RA, Evans AT, Fletcher RH, Fletcher SW: The effects of blinding on the quality of peer review: A randomized trial. JAMA 1990;263(10):1371-1376.

6. Godlee F, Gale CR, Martyn CN: Effect on the quality of peer review of blinding reviewers and asking them to sign their reports. A randomized controlled trial. JAMA 1998;280(3): 237-240.
7. van Rooyen S, Godlee F, Evans S et al: Effect of open peer review on quality of review and on reviewers' recommendations: a randomised trial. BMJ 1999;318(7175):23-27.

8. Justice AC, Cho MK, Winker MA et al: Does masking author identity improve peer review quality?: A randomized controlled trail. JAMA 1998;280(3):240-242.

9. Walsh E, Rooney M, Appleby L, Wilkinson G: Open peer review: a randomized controlled trial. British Journal of Psychiatry 2000;176:47-51.

10. Anonymous: Opening up peer review. Nature Cell Biology 2007;9(1):1. 